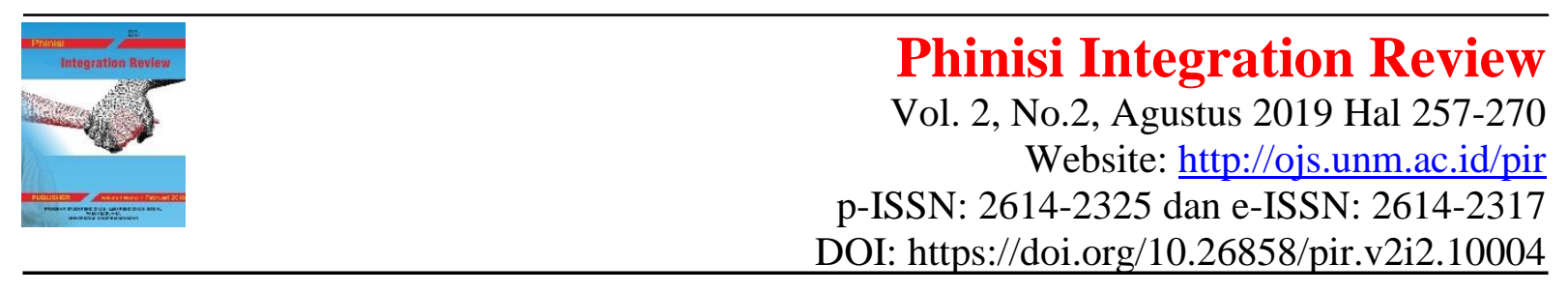

\title{
Dampak Perceraian Orang Tua Dalam Kehidupan Sosial Anak
}

\author{
Andi Irma Ariani \\ Pendidikan IPS Kekhususan Pendidikan Sosiologi, Universitas Negeri Makassar \\ Email: airmaariani@gmail.com
}

\begin{abstract}
Abstrak. Penelitian ini bertujuan untuk mengetahui, mengkaji, dan menjelaskan (i) Penyebab terjadinya perceraian, (ii) Dampak perceraian orang tua dalam kehidupan sosial anak. Penentuan informan pada penelitian ini menggunakan teknik purposive sampling. Teknik purposive sampling adalah teknik penentuan sampel dengan pertimbangan tertentu, dimana peneliti cenderung memilih informan secara variatif berdasarkan (alasan), yang jumlahnya adalah 30 orang dari 7 keluarga. Informan pendukung pada subjek penelitian ini adalah pasangan suami isteri yang bercerai (usia 20-56 tahun), anak (usia 6-22 tahun), orang tua/mertua (usia 60-70 tahun). Hasil penelitian ini menunjukkan bahwa: (i) Penyebab terjadinya perceraian dalam kehidupan sosial anak adalah hancurnya hubungan rumah tangga pasangan suami isteri yang menyebabkan perceraian dipicu berbagai macam sebab, diantaranya tidak harmonisnya hubungan suami isteri dari segi pemenuhan kebutuhan biologis, persoalan prinsip hidup yang berbeda, perbedaan penghasilan dalam peningkatan kesejahteraan hidup, adanya perselingkuhan, yakni Pria Idaman Lain (PIL) dan Wanita Idaman Lain (WIL) sebagai pihak ketiga perusak hubungan rumah tangga, perbuatan-perbuatan yang melanggar peran dan fungsinya masing-masing sebagai suami atau isteri, seperti Kekerasan Dalam Rumah Tangga (KDRT) dan adanya pengaruh dukungan sosial dari pihak luar. (ii) Dampak perceraian orang tua dalam kehidupan sosial anak adalah kenakalan remaja, stress, phobia, sedih dan bingung menghadapi masalah yang ada, tidak mampu mengungkapkan perasaan, adanya perasaan kehilangan orang tua, daya imajinatif berkurang, kurang percaya terhadap pasangan (bagi yang dewasa), dan kurang percaya diri baik dilingkungan sekolah maupun tempat tinggalnya.
\end{abstract}

Kata Kunci: Dampak Perceraian, Orangtua, Anak

Abstract. This study aims at examining and explaining (i) the causes of divorce, (ii) the impact of divorce in children's social lives. The determination of the research informants employed purposive sampling technique where it applied certain consideration, which the researcher tended to choose various informants based on the reasons with the total of 30 pepole from 7 families. The supporting informants of the research subiects were spouses, divorced husbands and wives, with the ranges of age (20-56 years), children (6-22 years), and parents/father-mother in laws (60-70 years). The results of the study reveal that (i) the cause of divorce in children's social lives are disharmony of husband and wife relationships in terms of biological needs, problems on life principles, differences in income, infidelity, actions that violet the roles and functions of husband and wife such as domestic violence and social support from the outsiders, (ii) the impact of divorce in children's social lives are juvenile delinquency, stress, phobia, sad and confusion in facing the problems, unable to reveal their feelings, feeling of lost parents, imaginative power is reduced, lack of trust to partner (for adults), and lack of self confidence in school and residence.

Keywords: Impact Of Divorce, Parents, Children 


\section{PENDAHULUAN}

Pada umumnya setiap individu yang ingin membangun mahligai rumah tangga melalui ikatan pernikahan yang sakral bertujuan untuk mencapai kebahagiaan lahir dan batin. Namun, untuk mencapai kebahagiaan dalam hidup pernikahan ternyata tidaklah mudah karena banyak masalah yang harus dihadapi.

Fungsi utama dari pengasuhan anak adalah mempersiapkan seorang anak untuk menjadi manusia yang baik dan berkualitas didalam masyarakat. Orang tua dalam keluarga senantiasa berfungsi mengarahkan anak-anaknya agar bertingkah laku sesuai dengan norma-norma sosial serta nilai-nilai budaya. Anak yang menjadi korban perceraian orang tuanya sudah pasti sangat terpukul, mereka membutuhkan kasih sayang sepenuhnya dari orang tuanya, mereka berhak mendapatkan perlindungan dari orang tuanya.

Untuk itu, sebelum memasuki pernikahan perlu adanya penyesuaian terhadap pasangan hidup. Kebanyakan pasangan suami istri dengan usia perkawinan 1-7 tahun, menunjukkan adanya hubungan positif antara penyesuaian diri pada pasangan suami istri sebelum menikah dengan kebahagiaan dalam kehidupan keluarga. Semakin baik penyesuaian diri pasangan suami istri, maka semakin bahagia pernikahannya. Sebaliknya, semakin buruk penyesuaian diri pasangan suami istri, maka semakin tidak bahagia pernikahannya.

Abdul, (2003: 118) menyatakan bahwa: "Sungguh tidak ada kebajikan, berkah, dan kebahagiaan dalam kehidupan yang isinya hanya percekcokan, perselisihan dan perbedaan apapun penyebabnya. Terlebih jika terjadi antara sepasang suami isteri yang telah diikat oleh sebuah ikatan yang kuat karena problema dan perselisihan antara sepasang suami-isteri dapat melenyapkan berkah dari segala sesuatu baik itu harta benda, anak-anak, rumah, dan lain sebagainya. Sebagai akibatnya keutuhan rumah tangga pun menjadi pecah dan berpengaruh pada lenyapnya generasi penerus dan hancurnya masyarakat".

Hikmah dari pernikahan adalah membangun sebuah keluarga dan menciptakan kebahagiaan dengan keluarga tersebut. Akan tetapi, ketika dalam kehidupan keluarga terjadi sesuatu yang membuyurkan kebahagiaan ini, dan keadaannya telah sedemikian parah sampai pada batas yang sulit dalam menjalani kehidupan keluarga, maka tidak boleh tidak salah satunya media atau cara untuk memisahkan suami-isteri harus ada. Kita tidak boleh memaksakan untuk tetap berada dalam ikatan ini pada keduanya karena kebencian dari keduanya atau salah satu dan keduanya tidak bisa didamaikan, maka Allah mensyariatkan talak, dan menjadikannya "halal yang dibenci". Ia adalah obat yang paling pahit dan paling keras, jiwa-jiwa menjadi sedih, rumah tangga buyar dan kadang-kadang anak-anak ikut terlantar meskipun demikian, tetap ada hikmah yang besar dan ketentuan cara islam ini.

Beberapa kesalahan yang dialami dalam sebuah keluarga adalah kesalahan dalam memilih pasangan, islam telah mewanti-wanti semenjak awal dalam hal memilih pasangan hidup untuk mengarungi bahtera rumah tangga, islam telah menggariskan dengan jelas bahwa pilihan yang baik adalah salah satu faktor yang dapat menciptakan kehidupan keluarga islami, harmonis, dan cinta kasih pada pasangan suami-isteri.

Faktor agama sebuah pilihan yang utama dan pokok, karena sering terjadi, cinta buta yang melanda orang yang ingin menjalani hidup berkeluarga membuatnya gegabah dan ceroboh dalam menentukan pilihan pasangannya. Sering kali hasrat biologis ataupun seksual mengalahkan akal sehatnya, sehingga ia terhanyut dalam hasratnya. Hanya disebabkan keelokan atau ketampanan wajah ia bisa tertipu, atau karena harta dan kedudukan yang tidak didukung dengan benteng agama dan akhlak mulia.

Oleh karena itu, kehidupan keluarga yang dibangunnya tersebut menjadi neraka yang selalu membakar sisi-sisi kehidupannya, bahkan bekas-bekas pun bisa menimpa kepada anak-anak mereka. 
Kesalahan dalam memilih pasangan hidup akan menyeret kepada retaknya hubungan dua kekasih dan terputusnya ikatan keluarga yang kemudian melahirkan permusuhan dan berakhir dengan perceraian, walaupun perceraian itu sesuatu yang boleh tetapi paling dibenci oleh Allah SWT.

Didalam masyarakat, kasus perceraian sering dianggap suatu peristiwa menegangkan dalam kehidupan keluarga dan senantiasa membawa dampak yang mendalam. Kasus ini menimbulkan stress, tekanan dan menimbulkan perubahan fisik, dan mental Dagun, (2002: 113). Kasus perceraian ada pula yang membawa kebahagiaan bathin kepada masing-masing pasangan namun itu terjadi pada perasaan orang tua saja bukan mempertimbangkan apa yang akan terjadi pada perasaan anak yang tercermin pada perilaku anak kelak.

Perceraian itu tidak hanya menyakitkan, menyedihkan tetapi juga membawa dampak sosial yang tidak kecil terutama bagi pasangan yang sudah memiliki keturunan. Oleh karena itu, sedapat mungkin dicari jalan yang lain (selain jalan perceraian). Namun apabila tidak ada jalan, maka jalan inilah yang harus diambil. Perceraian adalah "cerai hidup antara pasangan suami-isteri sebagai akibat dari kegagalan mereka menjalankan obligasi peran masingmasing" Ihromi, (2004: 137).

Dengan demikian ikatan suami isteri yang begitu kokoh, kuat dan dengan diselimuti perasaan kasih dan sayang yang dapat mendatangkan kedamaian dan kebahagiaan harus dilepas dan dipudarkan oleh sesuatu yang tidak satu prinsip.

Cinta kasih yang selama ini dibina dengan baik dan penuh kehati-hatian hingga ke jenjang perkawinan, harus berpisah padahal hal tersebut sudah jelas mendatangkan kesusahan, beban moral, belum lagi bila sudah punya anak. Kebahagiaan dan kesinambungannya sebuah rumah tangga adalah memang menjadi dambaan dan idaman semua orang, tetapi tidak semudah membalikkan telapak tangan, tidak semudah itu kita menghayal dan merencanakan.
Hal tersebut dapat digapai bila sebuah rumah tangga didasari dan mau menerjemahkan arti sebuah pernikahan dalam kehidupan. Sabar dalam menghadapi semua cobaan, mampu menepis segala rintangan yang akan menghadang dan menghancurkan berdirinya rumah tangga. Sebab bila tidak setiap orang yang berusaha menggapai kebahagiaan, derita mengikuti dibelakangnya, sekali saja langkah bahagia meleset maka derita mendahuluinya.

Langgeng dan berlangsungnya kehidupan rumah tangga merupakan suatu harapan dan tujuan akhir dari sebuah pernikahan yang didukung oleh Islam. Akad nikah dilakukan oleh kedua mempelai dihadapan penghulu, wali dan para saksi agar suami isteri dapat bersama-sama mengarungi samudera kehidupan baru selama ini belum pernah dialami dengan berbagai rintangan sebagai jelmaan ungkapan kasih sayang yang selama ini dicita-citakan. Mereka sudah selayaknya merasa hidup damai dan bahagia karena dapat hidup dengan sah bersama orang yang sudah lama dicintai dan diidam-idamkan dalam angannya dan yang sering menjadi awal dari kehancuran sebuah pernikahan adalah adanya pengkhianatan terhadap janji setia, hal ini menjadi tanggung jawab kedua suami isteri, jika keduanya menghendaki rumah tangganya disertai Allah, dibimbang tatkala kebingungan, ditolong tatkala kesusahan maka keduanya harus menjaga kesetiaan masing-masing. Sebaliknya, kalau salah satu mulai berbohong, menodai kesetiaan, hakikatnya, dia telah berulah dan bersedia ditinggalkan Allah.

Menurut UU No.1 Tahun 1974, pernikahan adalah ikatan lahir batin antara seorang laki-laki dan perempuan sebagai suami-istri dengan tujuan membentuk keluarga, rumah tangga yang bahagia dan kekal berdasarkan Ketuhanan Yang Maha Esa. Sedangkan menurut pandangan islam, pernikahan adalah suatu bentuk ibadah dimana seorang laki-laki dan perempuan melakukan akad dengan tujuan meraih kehidupan yang sakinah (tenang, damai), mawaddah (saling mencintai dan penuh kasih sayang), serta warahmah (kehidupan yang dirahmati Allah) Thobroni, (2010: 11). 
Watiniyah, (2015: 311) secara umum, kebahagiaan menikah itu dapat di perinci sebagai berikut: Pertama, kebutuhan biologis tersalurkan. Manusia butuh pemenuhan biologis. Tuhan berkuasa untuk memberikan hasrat biologis kepada manusia, jin, dan hewan. Bagi manusia dan jin, tujuannya agar mereka bisa berkembang biak dan semakin banyak makhluk yang menyembah-Nya. Manusia dan jin punya peraturan yang mengharuskan menikah dahulu agar bisa menyalurkan hasrat dengan sah. Berbeda dengan hewan yang bisa menyalurkannya kapan dan dimana saja. Kedua, lebih tenang dalam beribadah. Ketentraman hati otomatis akan berimbas pada kualitas ibadah. Ibadah yang kita lakukan akan menjadi lebih berkualitas apabila hati tenang. Ketiga, hati lebih tentram. Sudah bukan rahasia lagi bahwa laki-laki dan wanita adalah fitnah atau godaan bagi lawan jenisnya. Terutama wanita, ia menjadi fitnah atau godaan bagi lawan jenisnya. Terutama wanita, ia menjadi fitnah terbesar bagi laki-laki. Hanya karena memikirkan wanita, hati seorang laki-laki bisa gelisah dan pikirannya tak karuan. Tentu saja kondisi seperti ini tidak baik bagi hati dan agamanya.

Agama memberikan jalan keluar karena sesungguhnya laki-laki dan wanita itu saling membutuhkan dan tidak bisa hidup sendirian. Mereka membutuhkan pasangan hidup sehingga menikah dapat memenuhi kekosongan hidup mereka dan menjadikan hidup semakin tentram. Keempat, saling menasihati dan membimbing. Suami atau istri yang pintar agama akan memberikan nilai plus tersendiri dalam sebuah pernikahan. Ia bisa menasihati ketika berbuat kesalahan atau kealpaan. Ia juga dapat membimbing agar senantiasa ingat kepad Tuhan, mengamalkan sunah nabi dan kebaikan lainnya. Tentu saja kondisi ini merupakan kebahagiaan terbesar yang tak bisa tergantikan. Semakin sering di bimbing, tentu saja akan semakin bagus kualitas agama kita. Apabila kualitas agama meningkat, berarti kualitas iman juga akan semakin terjaga dan hidup semakin berarti.
Oleh karena itu, pilihlah pasangan yang lebih mengutamakan agama agar dapat saling menasihati dan membimbing menuju hidup yang bahagia di dunia dan akhirat. Kelima, saling melayani dan merawat. Waktu bujangan atau gadis, hidup akan lebih banyak dihabiskan sendirian. Mengurus diri sendiri dan mengerjakan apaapa sendiri, kecuali jika selalu di layani orang tua atau pelayan. Ketika sudah menikah, kondisi menjadi berubah. Keduanya bisa saling melayani sesuai dengan bagian masing-masing dalam suka dan duka, keduanya bisa melayani dan merawat. Keenam, saling membantu. Kebahagiaan lain yang di rasakan setelah menikah adalah setiap orang dapat saling membantu sehingga beban pekerjaan menjadi lebih ringan.

Pernikahan yang terjadi antara dua insan suami-isteri, sesungguhnya yang terlibat tidak sebatas kedua suami-isteri itu saja, melainkan melibatkan berbagai pihak seperti adanya unsur perselingkuhan, serta adanya unsur terutama kedua keluarga besar dari keduanya yang terlalu ikut campur.

Pernikahan memang sampai mengubah status hubungan orang lain, menjadi menantu dan mertua, orang lain menjadi adik dan kakak ipar, dengan ketentuan-ketentuan hukum tertentu. Hubungan suami-isteri terkadang menjadi baik dengan peran positif dari orang-orang tersebut, namun tidak jarang justru keterlibatan para pihak ini menjadikan pernikahan semrawut, dan kacau balau, orang tua dan mertua yang melibatkan diri kepada keluarga anak-menantunya sering menjadi biang malapetaka, apalagi jika ada unsur idaman lain maka akan membuat rumah tangga semakin parah.

Setiady, (2008: 267) mengatakan bahwa perceraian dalam hukum adat merupakan peristiwa yang luar biasa, problem sosial dan yuridis yang penting dalam kebanyakan daerah di Indonesia. Putusnya perkawinan dikarenakan perceraian baik menurut hukum adat maupun menurut hukum agama adalah perbuatan tercela. Dikalangan masyarakat 
terjadinya perceraian dari suatu perkawinan berarti akan putusnya atau renggangnya hubungan kekerabatan antara pihak kerabat yang bersangkutan.

Arifin, (2016: 322) mengatakan bahwa hak suami memutuskan pernikahan namanya talak atau cerai, hak talak ini sampai tiga kali. Hak isteri minta cerai yang disebut khulu' harus memiliki alasan yang dibenarkan syariat. Namun, jika seorang isteri ditalak dia lebih berhak untuk mengurusi anaknya dari pada suaminya selama wanita tersebut belum menikah lagi. Jika dia menikah, maka suaminya yang lebih berhak untuk mengurusinya.

Sa'suddin, (2000: 44) mengatakan bahwa perkawinan di syariatkan oleh Islam untuk mengembangbiakkan generasi manusia. Islam telah mensyariatkan caracara yang dapat menjamin berjalannya hubungan keluarga secara stabil. Islam memerintahkan berbuat baik terhadap keluarga, sabar menghadapi kekurangankekurangan antara suami-isteri, bersikap kasih sayang, lemah lembut, dan sebagainya.

$$
\text { Adapun perempuan yang }
$$

mengabaikan penampilannya atau tidak bersolek sedikit pun, maka jangan menyalahkan suami jika ia kemudian meninggalkan rumah atau muncul masalah rumah tangga baru yang banyak. Pengabaian yang dilakukan isteri ini bisa jadi berakibat pada kejiwaan suami. Perempuan yang ideal adalah perempuan yang tidak tertuju hanya pada satu lifestyle tertentu. Ia harus memperhatikan gaya berpakaiannya, cara berdandannya, begitu pula cara mengatur rumahnya serta bagaimana menyiapkan makanan untuk suaminya. Haruslah pandaipandai mengatur penampilan dari waktu ke waktu lainnya. Sehingga tetap menawan dimata suami sehingga mendapatkan lebih dari pada cinta seorang suami.

Untuk mengatasi ini semua, Islam telah menerapkan berbagai solusi atau cara penyelesaian yang dapat mengakhiri perselisihan antara sepasang suami-isteri, menghilangkan kebencian, dan membebaskan keduanya dari pertentangan- pertentangan yang membuat keadaan rumah tangga kembali menjadi tenang, sehingga tetap diliput oleh kebajikan, berkah, serta kebahagiaan yakni dengan semakin mendekatkan diri dengan Sang Pencipta.

Faktor lain yang sering menjadi bibit gagalnya sebuah rumah tangga adalah tidak tertunaikannya kewajiban suami-isteri, atau sebaliknya tidak diperolehnya hak suamiisteri dalam keluarga itu.

Walaupun perceraian itu merupakan gejala yang dapat dijumpai pada setiap masyarakat, akan tetapi terdapat masyarakat yang pada dasarnya tidak mengenal adanya perceraian atau dengan kata lain, perceraian itu hanyalah mungkin apabila memang keadaannya sudah sangat tidak mungkin lagi untuk diselesaikan. Alasan-alasan terjadinya perceraian itu sangatlah bervariasi. Tetapi dari variasi itu terdapat hal yang sama, yaitu pada umumnya alasan dari terjadinya perceraian adalah karena zina yang dilakukan oleh pihak isteri.

Hadikusuma,

(1995:

menyatakan bahwa bercampurnya pria dengan wanita yang bersetubuh tidak dalam ikatan perkawinan yang sah baik hal itu dilakukan antara pria dan wanita yang sudah atau sedang dalam ikatan perkawinan maupun antara pria dan wanita yang tidak/belum ada ikatan perkawinan ataupun diantara yang sudah kawin dan belum kawin. "Barangsiapa melakukan perbuatan zina, sedangkan yang melakukan itu belum pernah kawin maka menurut Hukum Islam dapat dijatuhi hukuman "dera seratus kali" dan dibuang keluar negeri satu tahun lamanya. Apabila yang melakukan zina itu ialah orang yang telah pernah kawin (bersetubuh) dapat dijatuhi hukuman "rajam" yaitu dilontar dengan batu sampai mati. Dikalangan masyarakat adat dimasa sekarang yang masih berlaku adalah hukuman "buang" atau "pengusiran" dari kampung”.

Dalam rumah tangga muslim, kewajiban suami menjadi hak dari isterinya, dan sebaliknya kewajiban isteri menjadi hak suaminya, adapun hak bersama, yang dimaksud dengan hak bersama, yakni antara 
kedua suami-isteri sama, yang ada pada suami dan ada pula pada isteri, hak disatu pihak menjadi kewajiban dipihak lain dalam bentuk dan sifat yang sama pula hak bersama itu ialah: memperoleh perlakuan baik serta saling memperoleh kenikmatan antara keduanya, hubungan mertua dan menantu dari keduanya, tetapnya status anak dan keturunan atas keduanya, saling menghormati dan menghargai satu sama lain, hak isteri atas suaminya yakni, seorang wanita yang bersedia dinikahi seorang pria sesungguhnya dia telah bersedia berkorban untuk suaminya dengan miliknya yang paling pribadi, atas dasar itu maka suami harus menembusnya dengan mahar ini karena mahar didalam alquran disebut nihlah (madu). Tidak terkendalinya emosi, yakni manakala satu pihak atau bahkan keduanya tidak dapat mengendalikan emosi saat marah.

Perlu disadari bahwa tidak akan pernah ada didunia ini rumah tangga yang tidak pernah berselisih antara anggotanya, karena bagaimana pun keluarga itu terdiri dari beberapa individu yang lahir dengan watak dan pribadi masing-masing dengan kepentingan masing-masing pula. Persoalan timbul, manakala terjadi perselisihan bahkan pertengkaran salah satu pihak tidak dapat mengendalikan emosinya, kata-kata kasar dan kotor sering meluncur bagai metraliur, bahkan terkadang sering berujung fisik berupa pemukulan.

Ketika hubungan pernikahan menjadi semakin renggang setelah melalui alur perjalanan dengan penuh cinta dan kasih sayang yang berlika-liku, jawabannya hanya satu yakni karena kesenjangan atau bahasa lain yang lebih muda diingat adalah pengabaian, yang dimaksud disini adalah sikap yang mengabaikan penampilan. Tidak perlu diragukan lagi bahwa hubungan pernikahan yang telah berlangsung lama menjadikan suami bersikap biasa terhadap isteri akan tetapi ketika isteri terlihat baru dan menarik, dengan memperhatikan penampilannya didalam rumah, serta ia tidak mengabaikan untuk merawat dirinya, maka hubungan diantara keduanya tentu akan semakin harmonis. Isteri harus terus memperhatikan perawatan tubuhnya demi sang suami yang akan menjadikan suami tersebut semakin rindu dan cinta terhadap dirinya, dan oleh sebab itu problem rumah tangga diantara keduanya juga akan semakin berkurang.

Terkadang masalah ekonomi merupakan faktor yang sangat rentan dalam menimbulkan problem rumah tangga, baik masalah ekonomi yang cukup bahkan berlebihan hingga masalah ekonomi yang kurang bahkan sangat berkekurangan ataupun masalah dalam pengaturan keuangan keluarga. Mereka yang memiliki penghasilan cukup dan hidup dalam kemapanan juga tak lepas dari masalah perekonomian seperti, hutang-piutang usaha, obsesi ingin semakin kaya sekalipun dengan cara yang haram, gaya hidup mewah, perebutan warisan dan sebagainya.

Sesungguhnya harta dan kekayaan yang Allah berikan kepada kita adalah suatu nikmat yang tidak diberikan kepada semua orang sekaligus merupakan ujian. Sebaliknya banyak orang yang hidupnya pas-pasan bahkan serba kekurangan ibarat pepatah mengatakan besar pasak dari pada tiang. Bagi mereka hidup adalah berpindah dari satu kesulitan ke kesulitan yang lain seolah dunia selalu menghimpit mereka dari segala arah sehingga segala tuntutan dan kesulitan hidup membuat permasalahan dalam rumah tangga.

Anak yang menjadi korban perceraian orang tuanya sudah pasti sangat terpukul, mereka membutuhkan kasih sayang sepenuhnya dari orang tuanya, mereka berhak mendapatkan perlindungan dari orang tuanya.

Anak akan merasakan kepedihan yang luar biasa dan sangat mendalam, tidak jarang anak malah menyalahkan dirinya sendiri serta menganggap bahwa merekalah tipe penyebab perceraian kedua orang tua mereka.

Jika perceraian dalam keluarga itu terjadi saat anak menginjak usia remaja, mereka mencari ketenangan entah ditetangga, sahabat atau teman sekolah, dan itu merupakan trauma yang mendalam, sedangkan bagi anak yang usia belum 
sekolah akan mengalami kesulitan dalam menyesuaikan diri menghadapi situasi yang baru. Berdasarkan beberapa konsep keluarga diatas, peneliti membangun asumsi bahwa latensi hilangnya peran dan fungsi sebuah keluarga bilamana terjadi perceraian. Perceraian dalam hal ini adalah terpisahnya hubungan suami isteri secara sah dimata hukum yang berlaku sehingga meniscayakan bentuk utuh "keluarga" yang seharusnya terdiri dari setidak-tidaknya ada suami dan isteri dan untuk pencapaian tujuan bersama dan Muhallil adalah seorang laki-laki yang menikahi seorang wanita yang telah diceraikan kembali agar bisa dinikahi oleh suaminya semula atau sering dikatakan dengan muhallil lahu. Dzahabi, (2002: 188).

Selain itu, efek perceraian pada remaja perempuan cenderung akan membuat mereka lebih tertekan dan terisolasi. "Mereka akan menutup diri. Sedangkan anak laki-laki cenderung meluapkannya. Mereka akan mengeskpresikan kemarahan mereka dengan cara yang berbeda. Kesedihan dan kemarahan itu muncul dikarenakan banyaknya hal yang harus dihadapi anak-anak. Seorang psikolog di Austin, Carl Pickhardt, mengatakan, anakanak pasti akan patah semangat karena merasa kehilangan, mereka merasa telah kehilangan keluarga utuh. Anak berasumsi bahwa orang tua mereka akan terus bersama dan keluarganya akan utuh. Sekarang orang tua mereka justru memutuskan untuk berpisah. Maka akan ada begitu banyak perubahan untuk menyesuaikan diri.

Selain itu anak merasa bahwa perginya salah satu orang tua meninggalkan mereka dikarenakan orang tua sudah tidak menyayangi mereka lagi, berbagai macam kepedihan dirasakan anak seperti terluka, bingung, marah, dan tidak aman serta sering pula berkhayal akan rujuknya kembali orang tua mereka. Hal ini diperkuat oleh reaksi fisik yang diunjukkan anak-anak berusia dibawah 9 tahun pada masa-masa konflik rumah tangga antara lain sering muntah, menjadi kurus, atau berat badan bertambah secara berlebihan, mengalami kerontokan rambut, bahkan ada yang menderita sakit kulit seperti bisul-bisul dan borok.

Pada setiap tingkat anak dalam menyesuaikan diri dengan lingkungan baru akan memperlihatkan cara dan penyelesaian yang berbeda. Kelompok anak yang belum berusia sekolah pada kasus perceraian terjadi, ada kecenderungan untuk mempersalahkan diri jika ia menghadapi masalah dalam hidupnya, ia menangisi dirinya. Umumnya anak usia kecil itu sering tidak betah, tidak menerima cara hidup yang baru. Ia tidak akrab dengan orang tuanya, anak ini sering dibayangi rasa cemas, selalu ingin mencari ketenangan.

Kelompok anak yang sudah menginjak usia besar pada saat terjadinya perceraian orang tuanya memberikan reaksi orang lain. kelompok anak ini tidak lagi menyalahkan diri sendiri, tetapi memiliki sedikit perasaan takut karena perubahan sistuasi keluarga dan merasa cemas karena ditinggalkan salah satu orang tuanya. Ketika anak sudah menginjak remaja, sudah mulai memahami seluk beluk arti perceraian, remaja memahami, apa akibat yang akan terjadi, mereka menyadari masalah-masalah yang akan muncul baik mengenai ekonomi, sosial, dan faktor-faktor lainnya.

Tahun pertama perceraian merupakan masa krisis yang paling sulit. Orang tua tampak dari waktu ke waktu memperlihatkan sikap kasar kepada anaknya. Namun, setelah dua tahun berikutnya, situasi mulai pulih kembali. Anak-anak dan orang tua sudah mulai beradaptasi dengan situasi. Ayah menjadi lebih keras dan disiplin, serta lebih mengekang anak-anaknya. Sementara ibu, cenderung membatasi diri. Tetapi bagi anak laki-laki meski sudah dua tahun berlalu, mereka tetap bersikap agresif, mudah terpengaruh, bersikap masa bodoh dengan ibunya. Sikap ini berbeda dengan anak putrid. Kisah-kisah perceraian itu lebih besar dampaknya pada anak laki-laki yang diasuh Ibu. Pernyataan tersebut tetap benar.

Peristiwa perceraian itu tidak menyenangkan karena kehidupan mapan yang dibangun sebelumnya berakhir dengan 
berantakan. Hubungan kasih sayang antara orang tua dengan anak terpaksa putus. Meski dalam kasus perceraian, kaum Ibu cenderung mengambil alih mengasuh anak, peranan ayah tetap penting. Hal yang paling penting adalah menjaga keintiman hubungan anak dengan kedua orang tua. Diungkap pula, orang tua yang kawin lagi dapat membawa masalah dalam keluarga.

Situasi keluarga baru ini menuntut anggota keluarga bersikap matang dalam mengatasi berbagai kesulitan yang timbul. Jadi, yang harus diperhatikan adalah bagaimana sang anak menghadapi kecemasan, kemarahan dan stres mereka. Salah satu cara yang bisa dilakukan adalah dengan membuat rutinitas baru untuk anak sesegera mungkin. Misalnya, dengan menulis daftar aturan baru, seperti jadwal kunjungan untuk anak-anak. Semakin cepat Anda memberikan struktur keluarga yang baru untuk anak-anak, maka akan semakin baik. Hal itu bertujuan untuk membuat anak-anak merasa nyaman dengan sistem terbaru. Orang tua dapat menentukan di mana anak akan tinggal dan bersekolah. Namun juga harus memiliki waktu yang fleksibel agar anak dapat menghubungi dan berbicara dengan orang tuanya kapan saja. Untuk itu, menurut Pickhardt, penting bagi pasangan yang akan bercerai untuk membaca buku soal perceraian ataupun mendatangi pakar konseling pernikahan.

Walaupun demikian, bila orang tua tiri dan orang tua kandung menciptakan situasi yang baik serta adanya kepekaan terhadap kebutuhan anak maka akan tercipta kebahagiaan dan ketentraman bahwa dari beberapa studi diketahui, anak-anak dari orang tua yang bercerai cenderung mengalami pencapaian tingkat pendidikan dan kondisi ekonomi yang rendah serta mengalami ketidakstabilan dalam perkawinan mereka sendiri, kemudian masalah kesulitan ekonomi khususnya dialami oleh anak-anak yang berada dibawah pengasuhan ibu dan berasal dari strata bawah. Secara lebih impresif bahwa kenyataannya keluarga berpenghasilan rendah mempunyai tingkat perceraian dan tingkat kematian lebih tinggi dibandingkan dengan keluarga-keluarga kaya.

Retaknya hubungan perkawinan melalui cerai antara suami dan isteri tentu saja akan menimbulkan dampak, terutama bagi pasangan yang telah memiliki anak. Beban sosial yang harus ditanggung anak akibat perceraian orang tua dapat menimbulkan berbagai dampak yang cenderung negatif.

Banyak hal yang diperlukan dan dibutuhkan dalam tumbuh kembang anak, lalu sebagaian anak tidak akan sepenuhnya tumbuh dan berkembang apabila ia hanya mendapatkan sebelah pihak kasih sayang dari orang tuanya, walaupun ada anak yang mampu melewati itu semua bahkan berhasil menggapai cita-citanya walau terjadi sebuah perceraian, karena ia mampu menjadikan pelajaran yang berharga dari perceraian orang tuanya untuk dijadikan semangat baru, dan memotivasi dirinya untuk sukses.

Hal ini tergantung dari usia anak pada saat perceraian, kondisi perceraian dan kepribadian anak. Sebagian anak akan mengalami kemunduran dalam belajar, sebagian anak mungkin akan merasa tidak akrab dengan orang tua ketika mereka sudah dewasa.

Berdasarkan hasil observasi awal menunjukkan bahwa keadaan sebelum perceraian lebih sulit dirasakan anak dari pada setelah perceraian terjadi. Menurut mereka, pertengkaran-pertengkaran yang terjadi sebelum perceraian membuat mereka tertekan atau stress. Beberapa tahapan kondisi lain yang dirasakan anak adalah masa setelah perceraian merupakan periode paling sulit dirasakan, masa transisi menjelang resminya perceraian orang tua serta saat perginya ayah meninggalkan rumah demi perempuan lain merupakan periode tersulit.

Anak yang orang tuanya bercerai pada saat berusia 5 tahun/lebih kecil, tidak merasa memiliki ikatan khusus/memiliki perasaan tidak nyaman bersama orang tuanya lebih besar dibandingkan anak yang orang tuanya bercerai setelah ia berumur 5 tahun.

Namun yang pasti, anak yang menghadapi orang tua bercerai akan merasakan kaget, sedih, cemas, marah/bingung pada saat yang bersamaan. Anak juga akan lebih mengalami masalah dalam bersosialisasi. Ini adalah kondisi dimana anak akan merasa rendah diri dan merasa iri pada anak yang memiliki keluarga yang utuh. Walaupun sebagian anak 
juga bisa melewati masa stress dan justru tumbuh menjadi pribadi yang lebih baik.

Disamping itu, resiko negatif juga akan dirasakan oleh anggota keluarga, yang terkait dan berhubungan erat dengan marital distress, konflik marital dan kekacuan kondisi perkawinan tersebut. Misalnya, efek yang merusak bagi perkembangan psikologis anak-anak mereka, termasuk depresi, menarik diri dari pergaulan sosial, kompetensi sosial yang rendah, persoalan keehatan terabaikan, performasi akademik yang menurun dan rendah, serta berbagai persoalan gangguan perilaku anak yang erat kaitannya dengan kesukaran emosional yang dihadapi anak-anak dari pasangan yang berada dalam kondisi konflik dalam proses menuju pada keputusan perceraian. "Perceraian sangat mahal harganya". Artinya banyak hal yang harus dibayar karena begitu banyak konsekuensi negatif yang menjadi risiko perceraian, baik bagi individu maupun lingkungan sosialnya.

Anak yang diasuh hanya oleh ayah saja atau ibu saja sangatlah berat, dan itu sangat dipengaruhi oleh faktor-faktor diantaranya pendidikan, faktor stratifikasi sosial, faktor mata pencaharian. Selain itu faktor lingkungan seperti tempat tinggal dan siapa-siapa yang tinggal dalam satu rumah yang ikut terlibat langsung maupun tidak langsung dalam proses pengasuhan yang meliputi orang-orang dekat dari anak bahkan orang-orang diluar lingkungan keluarga karena turut pula mempengaruhi sistem pengasuhan anak dan berdampak pada perilakunya.

Suami dan isteri yang bercerai boleh jadi belum mempunyai anak, tetapi boleh jadi telah mempunyai anak, inilah dampak perceraian terhadap mereka. Kejadian yang disaksikan ditengah masyarakat antara suami-isteri yang telah bercerai adalah timbulnya permusuhan atau sikap saling membenci. Bahkan bila mereka telah mempunyai anak, anak-anak tersebut mengalami penderitaan moral atau material. Kenyataan semacam ini membuat banyak orang merasa sangat cemas dengan perceraian, bahkan mengecam perceraian sebagai suatu tindakan yang menghancurkan masa depan anak-anak.

Kita perlu memahami secara benar maksud perceraian yang digariskan oleh Islam agar kita tidak tersesat dalam memahaminya karena kenyataan yang terdapat dalam masyarakat memang menimbulkan kecemasan dan rasa ngeri kita atas nasib anak-anak dan keluarga yang bercerai. Kenyataan-kenyataan pahit yang muncul ditengah masyarakat kita disebabkan perceraian bukanlah karena ketentuan perceraian itu sendiri, tetapi karena orang-orang yang melakukannya berbuat keliru dan salah. Kekeliruan dan kesalahan mereka mengabaikan apapun ajaran Allah dan Rasul-Nya dalam kehidupan ini. Jadi, pokok pangkal kerusakan akibat perceraian adalah perilaku mereka yang sudah jauh dari tuntunan Islam, bukan karena ketentuan-ketentuan itu sendiri. Sebab perceraian yang diatur dalam Islam juga terjadi pada masa sahabatsahabat Rasulullah dan dihadapan Rasulullah SAW sendiri namun tidak mengakibatkan dampak negatif pada anak dan isteri yang mengalami perceraian.

Ruswandi, (2013: 204) Kasih sayang merupakan cinta yang bersifat batiniah, kasih sayang merupakan perhatian seseorang pada orang lain untuk memberi dan menerima, kasih sayang ini kepada orang yang lebih tua, sebayanya atau yang lebih muda. Bentuknya seperti kasih sayang orang tua kepada anaknya atau sebaliknya sehingga membuat hubungan antara orang tua dengan anak menjadi akrab, namun perubahan drastis dapat terjadi apabila orang tuanya memutuskan untuk mengakhiri mahligai kehidupan rumah tangganya.

Affandi, (2007: 17) Anak dalam pemaknaan yang umum memiliki aspek yang sangat luas, tidak saja hanya disoroti dari satu bidang kajian ilmu saja melainkan dari berbagai bidang kajian baik dari sudut pandang agama, hukum, sosial-budaya, ekonomi, politik, dan aspek disiplin ilmu yang lainnya. Makna anak dari berbagai cabang ilmu akan memiliki perbedaan baik secara substansial, fungsi, dan tujuan. Nilai 
kita disoroti dari sudut pandang agama pemaknaan anak diasosiasikan bahwa anak adalah makhluk ciptaan Allah, yang daif dan berkedudukan mulia, dimana keberadaannya melalui proses penciptaan yang berdimensi kewenangan kehendak Allah.

Simmel dalam Ranjabar, (2013: 228) memandang konflik merupakan sesuatu yang tidak terhindarkan didalam suatu masyarakat meskipun mempunyai kesamaan pandangan semacam itu, terkait dengan kekerasan yang terjadi didalam konflik, simmel mengajukan proposisi tentang intensitas konflik "Semakin besar tingkat keterlibatan emosi didalam konflik, semakin cenderung konflik menjadi keras"

Teori yang digunakan dalam penelitian ini adalah teori dari Weber dalam (Wirawan, 2013: 69) yang mengistilahkan konflik sebagai suatu sistem "otoritas" atau sistem "kekuasaan". Perbedaan antara otoritas dan kekuasaan adalah kekuasaan cenderung menaruh kepercayaan pada kekuatan, sedangkan otoritas adalah kekuasaan yang telah mendapat pengakuan umum, pernyataan weber ini tentu saja dapat mengingatkan bahwa konflik adalah suatu realitas sosial, yang menyertai kehidupan sosial manusia. Oleh karena itu, haruslah senantiasa disadari agar kita tidak terbuai dalam mimpi yang membayangkan keadaan masyarakat tanpa ketegangan, tanpa percekcokan, ataupun tanpa perang. Konflik itu eksis dan hidup bersama kehidupan sosial masyarakat.

Alhayali, (2005: 1) mengatakan bahwa kehidupan berumah tangga melalui pernikahan merupakan salah satu lembaran hidup yang akan dilalaui oleh setiap manusia. Saat itulah kedewasaan pasangan suami-isteri sangat dituntut demi mencapai kesuksesan dalam membina bahtera rumah tangga. Tak selamanya keharmonisan akan selalu menjadi warna yang menghiasi hari-hari yang dilalui oleh pasangan suami-isteri. Kadang konflik bisa saja terjadi bahkan berbuntut kepada perceraian. Tergantung bagaimana pasangan suami-isteri itu bisa menyikapi dan mengedepankan akal sehat demi terjaganya keutuhan sebuah rumah tangga yang sakinah. Konflik yang terjadi didalam sebuah rumah tangga adalah sebagai suatu permasalahan yang cukup besar, karena setidak-tidaknya konflik antara suami-isteri yang dibiarkan berlarut-larut bisa mempengaruhi kejiwaan anak-anak dan pertumbuhan emosional mereka.

Dalam penelitian ini, masalah yang akan dikaji adalah penyebab terjadinya perceraian dan dampak perceraian orang tua dalam kehidupan sosial anak.

Penelitian ini memiliki tujuan untuk mengetahui, mengkaji, dan menjelaskan: (1) Terjadinya perceraian di Kelurahan Tetebatu Kecamatan Pallangga Kabupaten Gowa; (2) Dampak perceraian orang tua dalam kehidupan sosial anak di Kelurahan Tetebatu Kecamatan Pallangga Kabupaten Gowa

\section{METODE PENELITIAN}

Penelitian ini merupakan jenis penelitian kualitatif tipe deskriptif, data yang dikumpulkan lebih mengambil bentuk kata-kata atau gambar dari pada angka-angka sebagai alat metode utamanya Kaelan, (2012: 12). Bogdan dan Taylor dalam (Moleong, 2007:4) mendefinisikan metodologi kualitatif sebagai prosedur penelitian yang menghasilkan data deskriptif berupa kata-kata tertulis atau lisan dari orang-orang dan perilaku yang dapat diamati. Menurut mereka, pendekatan ini diarahkan pada latar dan individu tersebut secara holistik (utuh).

Lokasi penelitian adalah di Kelurahan Tetebatu Kecamatan Pallangga Kabupaten Gowa. tentang dampak perceraian orang tua dalam kehidupan sosial anak. Alasan pemilihan lokasi penelitian di Kelurahan Tetebatu Kecamatan Pallangga Kabupaten Gowa karena melihat begitu banyak perkara antara pasangan suami isteri sehingga menyebabkan perceraian dan menimbulkan dampak bagi kehidupan sosial anak dan menggunakan pendekatan studi kasus, dimana menggunakan pendekatan studi kasus. Penentuan informan pada penelitian ini menggunakan Teknik Purposive Sampling. Subjek penelitian ini adalah: Pasangan suami isteri yang bercerai (Usia 20-56 tahun), Anak (Usia 6-22 tahun), Orang tua/mertua (Usia 60-70 tahun), Tokoh masyarakat, Ketua Pengadilan, Sekretaris Lurah/kepala desa, Ulama.

Instrumen penelitian adalah alat yang digunakan dalam mengumpulkan data, yang menjadi instrumen utama dalam penelitian ini adalah peneliti sendiri. Sebagai instrumen utama dalam penelitian ini maka, peneliti mulai tahap awal penelitian sampai pada hasil menggunakan pedoman observasi, pedoman wawancara, dan telaah dokumen. 
Teknik pengumpulan data merupakan sesuatu yang sangat penting dalam penelitian karena tujuan utamanya yaitu untuk mendapatkan data yang akurat. Adapaun teknik pengumpulan data yang digunakan dalam penelitian ini yaitu sebagai berikut: observasi, wawancara, dan dokumentasi.

Teknik pengabsahan data yang digunakan untuk menguji kredibilitas data dalam penelitian ini adalah member check. Sugiyono, (2014: 276) Member check merupakan proses pengecekan data yang berasal dari pemberi data dengan tujuan untuk mengetahui seberapa jauh data yang diperoleh sesuai dengan apa yang diberikan oleh pemberi data dan dilakukan untuk mengambil temuan kembali pada partisipan.

Teknik pengabsahan data dalam penelitian ini adalah data yang diperoleh dilapangan kemudian diolah secara deskriptif kualitatif dengan melalui tiga tahap yaitu reduksi data, penyajian data dan penarikan kesimpulan.

\section{HASIL DAN PEMBAHASAN}

\section{Penyebab Terjadinya Perceraian}

Perceraian pasangan suami isteri sebagaimana telah dikemukakan pada bab-bab terdahulu, dapat dilatarbelakangi oleh berbagai macam sebab, seperti ekonomi, perselingkuhan, beda pendapat, dan sebagainya. Perceraian dapat dilakukan oleh suami dengan menjatuhkan "talak" pada isterinya, tetapi juga dapat diajukan isteri dengan mengajukan "cerai gugat". Berkaitan dengan hal tersebut, data dan informasi dikumpulkan peneliti, seperti yang dikemukakan sekretaris lurah setempat yakni Ibu Kasmiah, S.Sos yang menyatakan bahwa dengan melihat kondisi bahwa tingginya angka perceraian yang terjadi di Kelurahan Tetebatu Kecamatan Pallangga, itu tidak dapat dipungkiri karena,

Pertama, tingkat kepadatan penduduknya cukup besar dibanding dengan kelurahan dan kecamatan lainnya. Kedua, pengaruh informasi melalui media televisi seperti sinetron yang mempertontonkan kasus kekerasan dalam rumah tangga, perselingkuhan, perkawinan usia muda, itu banyak yang ditiru oleh sebagian kecil masyarakat kita mengakibatkan terjadinya perceraian.

Ketiga, iman, yang kurang sehingga terpicu untuk terjadinya percekcokan dan berakhir dengan perceraian, kemudian dibarengi dengan faktor ekonomi. Senada dengan informan diatas, salah satu tokoh masyarakat menyatakan bahwa, memang perceraian di Kecamatan Pallangga ini khususnya di Kelurahan Tetebatu ini dikenal dengan kampung janda, melihat tingginya angka perceraian dilingkup sini, banyaknya janda-janda yang ada masih tergolong sangat muda sudah bercerai dengan suaminya. Perceraian ini terjadi karena persoalan ekonomi dan perselingkuhan, itulah yang paling dominan terjadi di daerah sini.

Penjelasan hasil wawancara informan berinisial $\mathrm{HN}$ bahwa terkadang saya meneteskan air mata karena kasihan dengan anak-anak saya yang masih kecil hidup tanpa mendapatkan lagi kasih sayang dari ayahnya. Walaupun saya tahu, bahwa awal mula dari percekcokan ini adalah dari saya sendiri yang bermain hati.

Senada pula dengan yang diatas, terdapat pula hasil wawancara dengan informan berinisal AN mengatakan bahwa perceraian kami terjadi pada saat itu dikarenakan faktor perselingkuhan, saya hanya pedagang kecilkecilan dan suami saya tidak bekerja, sementara suami saya berselingkuh dikamar dirumah mertua saya, apa yang saya mau pertahankan jika pernikahan ini sudah dikotori dengan perzinahan. Dia adalah laki-laki yang tidak tahu diri, saya yang membiayai se Hasil penelitian menunjukkan bahwa penyebab terjadinya perceraian adalah hancurnya hubungan rumah tangga pasangan suami isteri yang menyebabkan perceraian dipicu berbagai macam sebab, diantaranya tidak harmonisnya hubungan suami isteri dari segi pemenuhan kebutuhan biologis, persoalan prinsip hidup yang berbeda, perbedaan penghasilan dalam peningkatan kesejahteraan hidup, adanya perselingkuhan, yakni Pria Idaman Lain (PIL) dan Wanita Idaman Lain (WIL) sebagai pihak ketiga perusak hubungan rumah tangga, perbuatanperbuatan yang melanggar peran dan fungsinya masing-masing sebagai suatu atau isteri, seperti Kekerasan Dalam Rumah Tangga (KDRT) dan adanya pengaruh dukungan sosial dari pihak luar.

Hasil penelitian menunjukkan bahwa penyebab terjadinya perceraian adalah hancurnya hubungan rumah tangga pasangan suami isteri yang menyebabkan perceraian dipicu berbagai macam sebab, diantaranya tidak harmonisnya hubungan suami isteri dari segi pemenuhan kebutuhan biologis, persoalan 
prinsip hidup yang berbeda, perbedaan penghasilan dalam peningkatan kesejahteraan hidup, adanya perselingkuhan, yakni Pria Idaman Lain (PIL) dan Wanita Idaman Lain (WIL) sebagai pihak ketiga perusak hubungan rumah tangga, perbuatan-perbuatan yang melanggar peran dan fungsinya masing-masing sebagai suatu atau isteri, seperti Kekerasan Dalam Rumah Tangga (KDRT) dan adanya pengaruh dukungan sosial dari pihak luar.

Hasil penelitian menunjukkan bahwa penyebab terjadinya perceraian adalah hancurnya hubungan rumah tangga pasangan suami isteri yang menyebabkan perceraian dipicu berbagai macam sebab, diantaranya tidak harmonisnya hubungan suami isteri dari segi pemenuhan kebutuhan biologis, persoalan prinsip hidup yang berbeda, perbedaan penghasilan dalam peningkatan kesejahteraan hidup, adanya perselingkuhan, yakni Pria Idaman Lain (PIL) dan Wanita Idaman Lain (WIL) sebagai pihak ketiga perusak hubungan rumah tangga, perbuatan-perbuatan yang melanggar peran dan fungsinya masing-masing sebagai suatu atau isteri, seperti Kekerasan Dalam Rumah Tangga (KDRT) dan adanya pengaruh dukungan sosial dari pihak luar.

luruh kebutuhannya malah yang saya terima adalah sebuah pengkhiatan darinya.

\section{Dampak Perceraian Orang Tua dalam Kehidupan Sosial Anak}

Perceraian itu tidak hanya menyakitkan, menyedihkan tetapi juga membawa dampak sosial yang tidak kecil terutama bagi pasangan yang sudah memiliki keturunan. Oleh karena itu, sedapat mungkin dicari jalan yang lain (selain jalan perceraian). Namun apabila tidak ada jalan, maka jalan inilah yang harus diambil.

Perceraian ada pula yang membawa kebahagiaan bathin kepada masing-masing pasangan namun itu terjadi pada perasaan orang tua saja bukan mempertimbangkan apa yang akan terjadi pada perasaan anak yang tercermin pada perilaku anak kelak.

Berdasarkan hasil wawancara dengan informan berinisial AS yang mengatakan bahwa, orang tuaku pisah, 'ayahku telah pergi bersama perempuan lain'. saya ingin mereka bersatu. Saya cinta kedua orang tuaku. saya tidak nakal, kenapa ayah pergi, kembalilah ayah, jangan tinggalkan saya sendiri. Ibu merindukanmu juga.

Senada dengan diatas, ST menyatakan bahwa, ibu telah pergi meninggalkanku, ibu selalu ingin membawaku pergi tapi nenek dan ayah marah jika saya ikut. Saya sayang semua, saya sayang ibu, saya ingin ikut tapi saya takut kena marahnya ayah. Saya tak mau mereka menghancurkan piring, saya sayang mereka. Senada dengan diatas, BS menyatakan bahwa, Saya harus rela, saya stress dengan ini semua, saya rela ditinggalkan oleh ibu saat masih berusia 5 tahun. Saya sampai detik ini belum merasakan kasih sayang ibu seutuhnya, saya membenci keadaan seperti ini. Tetapi "saya harus menerima dan ikhlas karna inilah fakta penghidupanku.

\section{Pembahasan}

\section{Penyebab Terjadinya Perceraian di Kelurahan Tetebatu Kecamatan Pallangga Kabupaten Gowa}

Ikatan suami isteri yang begitu kokoh, kuat dan dengan diselimuti perasaan kasih dan sayang yang dapat mendatangkan kedamaian dan kebahagiaan harus dilepas dan dipudarkan oleh sesuatu yang tidak satu prinsip. Cinta kasih yang selama ini dibina dengan baik dan penuh kehati-hatian hingga ke jenjang perkawinan, harus berpisah padahal hal tersebut sudah jelas mendatangkan kesusahan, beban moral, belum lagi bila sudah punya anak.

Kebahagiaan dan kesinambungannya sebuah rumah tangga adalah memang menjadi dambaan dan idaman semua orang, tetapi tidak semudah membalikkan telapak tangan, tidak semudah itu kita menghayal dan merencanakan. Hal tersebut dapat digapai bila sebuah rumah tangga didasari dan mau menerjemahkan arti sebuah pernikahan dalam kehidupan. Sabar dalam menghadapi semua cobaan, mampu menepis segala rintangan yang akan menghadang dan menghancurkan berdirinya rumah tangga. Sebab bila tidak setiap orang yang berusaha menggapai kebahagiaan, derita mengikuti dibelakangnya, sekali saja langkah bahagia meleset maka derita mendahuluinya.

Ansory, (2001: 139) mengatakan bahwa Perceraian adalah melepaskan atau meninggalkan, menurut agama adalah melepaskan ikatan perkawinan atau bubarnya ikatan perkawinan, perpisahan adalah hasil akhir yang terjadi dalam tubuh keluarga (suami-isteri). Tiada sebab tanpa akibat, sebab muncul akibat pun datang. Hampir segala sesuatu didunia ini mengikuti hukum sebab akibat. Bila ada sebabsebab yang dapat menghantar bahagia, juga ada sebab-sebab yang menghalangi datangnya bagian diantaranya ialah perceraian. 
Silalahi, (2010: 31) mengatakan bahwa untuk membentuk sebuah konsep keluarga dalam kehidupan pernikahan tidaklah mudah. Meskipun hanya dilakukan oleh dua individu, namun tentunya masing-masing mempunyai prinsip dasar yang berbeda-beda sebelum penyatuan prinsip dasar, hendaknya pasangan membicarakan prinsip masing-masing melihat dan mengakui kelebihan dan kekurangan prinsip dasar tersebut.

Hasil penelitian menunjukkan bahwa penyebab terjadinya perceraian adalah hancurnya hubungan rumah tangga pasangan suami isteri yang menyebabkan perceraian dipicu berbagai macam sebab, diantaranya tidak harmonisnya hubungan suami isteri dari segi pemenuhan kebutuhan biologis, persoalan prinsip hidup yang berbeda, perbedaan penghasilan dalam peningkatan kesejahteraan hidup, adanya perselingkuhan, yakni Pria Idaman Lain (PIL) dan Wanita Idaman Lain (WIL) sebagai pihak ketiga perusak hubungan rumah tangga, perbuatan-perbuatan yang melanggar peran dan fungsinya masing-masing sebagai suatu atau isteri, seperti Kekerasan Dalam Rumah Tangga (KDRT) dan adanya pengaruh dukungan sosial dari pihak luar.

\section{Dampak Perceraian Orang Tua dalam Kehidupan Sosial Anak di Kelurahan Tetebatu Kecamatan Pallangga Kabupaten Gowa}

Tidak meragukan lagi, berbicara tentang konflik dalam sebuah keluarga akan membawa kita kedalam perbicangan yang begitu luas dan urgent, dikatakan luas karena faktior penyebabnya bercabang-cabang dan sangat berkaitan, dan dikatakan urgent karena ia dapat membuka mata dan pandangan kita akan bahaya yang ditimbulkannya.

Perceraian bagi anak adalah "hilangnya kasih sayang" keutuhan keluarganya, rasanya separuh "diri" anak telah hilang, hidup tak akan sama lagi setelah orang tua mereka bercerai dan mereka harus menerima kesedihan dan perasaan kehilangan yang mendalam.

Banyak faktor yang terlebih dahulu diperhatikan sebelum menjelaskan tentang dampak perkembangan anak setelah terjadi suatu perceraian antara ayah dan ibu mereka.

Anak merupakan korban yang paling terluka ketika orang tuanya bertengkar atau memutuskan untuk bercerai. Takut dan kehilangan adalah perasaan yang selalu ada di benak mereka. Jalaluddin, (2002: 106) mengatakan bahwa kehidupan rumah tangga yang kurang harmonis umumnya dapat menjurus kepada pertengkaran terbuka antara bapak dan ibu

Hasil penelitian menunjukkan bahwa dampak perceraian orang tua dalam kehidupan sosial anak adalah kenakalan remaja, stress, phobia, sedih dan bingung menghadapi masalah yang ada, tidak mampu mengungkapkan perasaan, adanya perasaan kehilangan orang tua, daya imajinatif berkurang, kurang percaya terhadap pasangan (bagi yang dewasa), dan kurang percaya diri baik dilingkungan sekolah maupun tempat tinggalnya.

\section{SIMPULAN DAN SARAN}

Kesimpulan dalam penelitian adalah (1) Penyebab terjadinya perceraian di Kelurahan Tetebatu Kecamatan Pallangga Kabupaten Gowa adalah hancurnya hubungan rumah tangga pasangan suami isteri yang menyebabkan perceraian dipicu berbagai macam sebab, diantaranya tidak harmonisnya hubungan suami isteri dari segi pemenuhan kebutuhan biologis, persoalan prinsip hidup yang berbeda, perbedaan penghasilan dalam peningkatan kesejahteraan hidup, adanya perselingkuhan, yakni Pria Idaman Lain (PIL) dan Wanita Idaman Lain (WIL) sebagai pihak ketiga perusak hubungan rumah tangga, perbuatanperbuatan yang melanggar peran dan fungsinya masing-masing sebagai suatu atau isteri, seperti Kekerasan Dalam Rumah Tangga (KDRT) dan adanya pengaruh dukungan sosial dari pihak luar; (2) Dampak perceraian orang tua dalam kehidupan sosial anak di Kelurahan Tetebatu Kecamatan Pallangga Kabupaten Gowa adalah bahwa kenakalan remaja, stress, phobia, sedih dan bingung menghadapi masalah yang ada, tidak mampu mengungkapkan perasaan, adanya perasaan kehilangan orang tua, daya imajinatif berkurang, kurang percaya terhadap pasangan (bagi yang dewasa), dan kurang percaya diri baik dilingkungan sekolah maupun tempat tinggalnya.

Berdasarkan kesimpulan yang dikemukakan diatas, maka saran yang dapat peneliti kemukakan sehubungan dengan hasil penelitian ini antara lain: (1) Diharapkan pada orang tua, agar kiranya tidak intervensi, tetap memberikan perhatian sebaik mungkin, berpisah bukan berarti terputus tali darah antara ayah/ibu ke anak; (2) Kepada anak, jangan merasa bahwa perceraian ini merupakan tanda hilangnya kasih sayang, jangan berpikir bahwa tidak ada lagi 
kasih sayang yang didapatkan setelah perkara tersebut. Berpikirlah sebaik mungkin. "Cinta dan kasih orang tua tidak akan pernah pudar untuk anaknya".

\section{DAFTAR RUJUKAN}

Abdul, Abu. 2003. 15 Sebab Dicabutnya Berkah. Jakarta: Pustaka AlKautsar.

AlHayali Kamil. 2005. Solusi Islam Dalam Konflik Rumah Tangga. Jakarta: Grafindo.

Ansory, 2001. Jalan Kebahagiaan Yang Diridhai. Jakarta: Grafido.

Arifin, Gus. 2016. Menikah Untuk Bahagia. Jakarta: Gramedia.

Dagun, Save. 2002. Psikologi Keluarga. Jakarta: Rineka Cipta

Dzahabi, 2002. Al Kabair Galaksi Dosa. Jakarta: Darul Falah.

Hadikusuma, Hilman, 1995. Pengantar Ilmu Hukum Adat Indonesia. Bandung: Mandar Maju.

Ihromi, T.O, 2004. Bunga Rampai Sosiologi Keluarga. Jakarta: Yayasan Obor Indonesia.

Jalaluddin, 2002. Mempersiapkan Anak Saleh. Jakarta: Grafindo.

Kaelan, 2012. Metode Penelitian Kualitatif Interdisipliner. Yogyakarta: Paradigma.

Moleong, J.Lexy. 2007. Metodologi Penelitian Kualitatif. Bandung: Rosdakarya.

Ranjabar Jacobus, 2013. Sistem Sosial Budaya Indonesia. Bandung: Alfabeta.

Ruswandi, 2013. Psikologi Pembelajaran. Bandung: Cipta Pesona Sejahtera.

Sa'suddin, 2000. Upaya Musuh

$$
\begin{aligned}
& \text { Menghancurkan Islam Melalui } \\
& \text { Keluarga. Bandung: Irsyad Baitus } \\
& \text { Salam. }
\end{aligned}
$$

Setiady, Tolib. 2008. Intisari Hukum Adat Indonesia (Dalam Kajian Kepustakaan). Bandung: Alfabeta.

Silalahi, Karlinawati, 2010. Keluarga
Indonesia. Jakarta: Grafindo.

Sugiyono, 2014. Metode Penelitian

Kuantitatif Kualitatif dan $R \quad \& \quad D$. Jakarta: Alfabeta.

Thobroni, Munir, 2010. Meraih Berkah

Dengan Menikah. Yogyakarta: Pustaka Marwa.

Watiniyah Ibnu, Ummu Ali. 2015. Hadiah Pernikahan Terindah. Jakarta: Kaysa Media.

Wirawan, 2013. Teori-Teori Sosial Dalam Tiga Paradigma. Jakarta: Kencana. 